\title{
PENGARUH INOVASI DAN KUALITAS PRODUK TERHADAP MINAT BELI ULANG KONSUMEN BREADTALK LOMBOK EPICENTRUM MALL
}

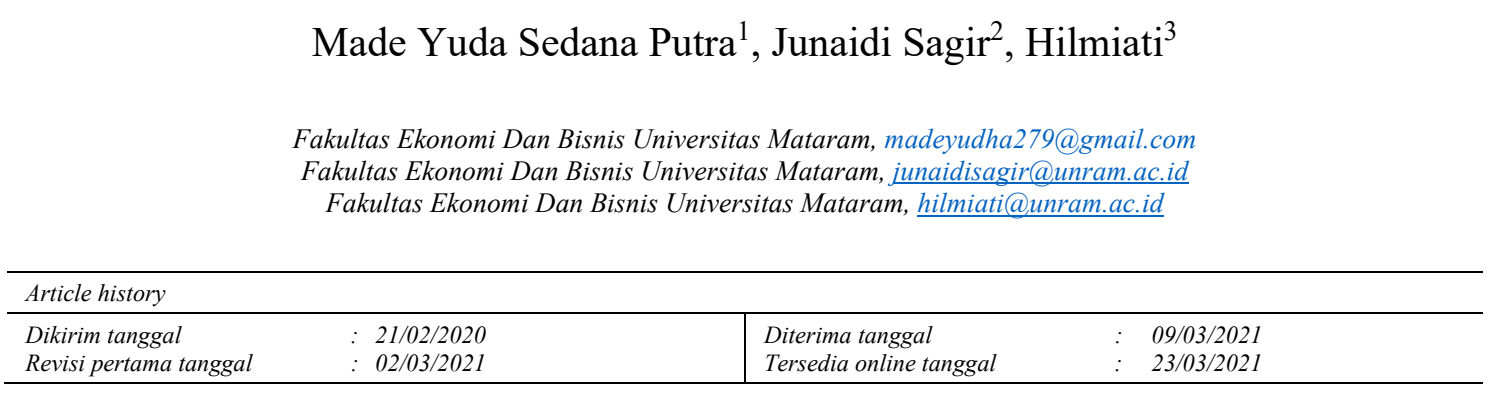

\begin{abstract}
ABSTRAK
Penelitian ini menguji pengaruh inovasi dan kualitas produk terhadap minat beli ulang konsumen Breadtalk Lombok Epicentrum Mall. Lokasi penelitian dilakukan di Lombok Epicentrum Mall Mataram. Penelitian ini merupakan penelitian kuantitatif asosiatif yang dilakukan dengan metode pengumpulan data sample survey, dan teknik pengambilan sampel nonprobabiliti sampling dengan kemudian dianalisis menggunakan Regresi Linier berganda.

Hasil dari penelitian ini menyatakan bahwa variabel Inovasi dan Kualitas Produk memiliki pengaruh yang signifikan terhadap minat beli ulang konsumen produk Breadtalk Lombok Epicentrum Mall Mataram. Dengan variabel yang paling dominan mempengaruhi yaitu variabel kualitas produk.
\end{abstract}

Kata Kunci : Inovasi Produk, Kualitas Produk, Minat Beli Ulang

\section{ABSTRACT}

This study examines the effect of innovation and product quality on consumers' buying interest in Breadtalk Lombok Epicentrum Mall. The location of the study was conducted at Lombok Epicentrum Mall. This research is an associative quantitative research conducted with sample survey data collection methods, and nonprobability sampling sampling techniques by then analyzed using multiple linear regression.

The results of this study state that the Product Innovation and Quality variable has a significant influence on the interest in repurchasing product consumers of Breadtalk Lombok Epicentrum Mall Mataram. With the most dominant variable affecting the product quality variable.

Keywords: Product Innovation, Product Quality, Repurchase Interest

\section{PENDAHULUAN}

Breadtalk merupakan pencipta trend lifestylebakery baru di Indonesia, mulai dari sistem franchise-nya yang dikelola secara modern mengikuti standar franchise makanan internasional lainnya, konsep gerai dengan open kitchen dan open display yang bertujuan menarik minat calon konsumen dengan memperlihatkan proses pembuatan roti menggunakan alat berteknologi tinggi, bau roti yang harum serta sistem open display yang membuat para calon konsumen merasa lebih bebas dalam memilih produk roti yang diinginkan. 
Breadtalk juga memiliki brand yang kuat melalui product differentiation dan inovasi yang konstan. Sampai saat ini Breadtalk berhasil menciptakan lebih dari 30 varian produk khususnya di gerai Breadtalk di Lombok Epicntrum Mall yang menawarkan gaya hidup baru dalam menyantap roti dan juga dengan varian rasa yang jelas berbeda dengan perusahaan roti lainnya. Untuk lebih menjelaskan inovasi yang dilakukan yaitu Breadtalk selalu memunculkan menu baru dengan perpaduan inovasi inovasi terbarunya yaitu champignon pizza dan hidden burger, serta tiga menu pendukung yaitu e-clair, spicy herbs, dan mount fuji.

Selain itu juga terdapat salah satu inovasi yang dilakukan oleh Breadtalk disaat menjelang peringatan hari raya yaitu dengan membuat suatu bingkisan kue atau parsel, yang dimana berisi beberapa produk dari Breadtalk khususnya dalam jenis kue kering. Hal ini dilakukan Breadtalk karena melihat kebiasaan masyarakat saat menjelang hari raya yang saling mengirim bingkisan untuk menjaga huungan baik antar sesama.

Adapun dari segi kualitasnya, Breadtalk membuat produk menggunakan mesinmesin, baik saat mencampurkan bahan-bahan maupun memasak. Disini tenaga manusia yang dilibatkan pada saat pencetakan roti, membuat toping roti. Mesin yang digunakan untuk membantu pembuatan roti pun diimpor dari mancanegara, dan begitu pula dengan lebih dari $50 \%$ bahan baku roti.

Kemudian untuk daya tahan dari produk Breadtalk yang sama sekali tanpa menggunakan bahan pengawet dapat bertahan selama dua hari, yang artinya dalam pembuatan roti sangat dijaga kualitas dan penggunaan bahan bakunya. Dalam hal penyajian, Breadtalk juga tetap mejaga kualitasnya dengan menjaga setiap roti yang akan disajikan tidak bersentuhan secara langsung dengan tangan melainkan menggunakan sarung tangan khusus.

Melihat ketatnya persaingan jaringan toko roti di kota Mataram, para pelaku usaha perlu melakukan inovasi dan strategi bisnis untuk menciptakan daya tarik produk yang tinggi melalui kualitas produk dan kemampuan berinovasi yang ditawarkan sehingga tercipta suatu daya tarik produk kuat yang secara bersama sama akan meningkatkan minat beli ulang konsumen.

\section{TINJAUAN TEORITIS}

\section{Inovasi}

Melakukan inovasi dalam bisnis adalah sangat penting untuk memperkuat daya saing dan daya tahan bisnis, apapun bisnisnya. Inovasi yang berkelanjutan akan menjamin kelanggengan bisnis dan dapat mempengaruhi keputusan pembelian konsumen. Inovasi diperlukan karena banyaknya produk sejenis sehingga dapat membedakannya dengan produk saingan.

Hill dan Sullivan (2004:214) menjelaskan bahwa inovasi juga dikenal sebagai pengembangan produk baru (New Product Develompment). Produk baru yang dimaksud sebagai produk orisinil adalah pengembangan produk, modifikasi produk, dan merek baru yang dikembangkan perusahaan melalui usaha riset dan pengembangan mereka sendiri. Myers dan Marquis dalam Kotler (2007:36) menyatakanbahwa inovasi produk adalah gabungan dari berbagai macam proses yang saling mempengaruhi. Selanjutnya menurut Assauri (2014:219) dikatakan bahwa inovasi produk atau pengembangan 
produk merupakan kegiatan atau aktivitas yang dilakukan dalam menghadapi kemungkinan perubahan produk ke arah yang lebih baik, sehingga dapat memberikan dayaguna maupun daya pemuas yang lebih besar.

\section{Kualitas Produk}

Menurut Kotler dan Armstrong (2012:283) kualitas produk adalah kemampuan sebuah produk dalam menjalankan fungsinya, hal itu termasuk daya tahan, kehandalan, ketapatan, kemudahan pengoperasian dan perbaikannya, serta lainnya. Sedangkan menurut Kotler dan Keller (2009:143) kualitas produk adalah totalitas fitur dan karakteristik produk atau jasa yang bergantung pada kemampuannya untuk memuaskan kebutuhan yang dinyatakan atau tersirat. Dipihak lain Walker et.al (2005:422) menyarankan apabila perusahaan ingin mempertahankan keunggulan kompetitipnya, maka mereka harus memahami dimensi dari kulaitas produk yang meliputi: Kinerja, daya tahan, kesesuaian dengan spesifikasi, fitur, kehandalan, estetika dan kesan kualitas.

\section{Minat Beli}

Minat beli merupakan kecenderungan sikap konsumen dalam perilaku pembelian yang didasari atas kebutuhan dan ketertarikan akan suatu produk dan dapat memicu pilihan konsumen terhadap suatu produk. Dengan inovasi dan kualitas produk yang baik, dan disertai strategi pemasaran yang tepat dapat mendorong pembelian konsumen yang merupakan hasil akhir dari proses pengambilan keputusan.

Menurut Kotler dan Keller (2009:15), menyatakan bahwa minat beli merupakan perilaku yang muncul sebagai respon terhadap obyek yang menunjukkan keinginan konsumen untuk melakukan pembelian. Minat beli adalah merupakan tahap akhir dari proses keputusan pembelian yang terbilang rumit. Proses ini dimulai dari kemunculan kebutuhan suatu produk yang dilanjutkan dengan pencarian informasi, setelah itu konsumen akan mengevaluasi produk tersebut yang kemudian memunculkan niat untuk membeli sebelum akhirnya memutuskan pembelian

Sedangkan minat beli ulang menurut Anoraga (2005:288) merupakan suatu proses pengambilan keputusan yang dilakukan oleh konsumen sesudah mengadakan pembelian atas produk yang ditawarkan atau dibutuhkan oleh konsumen tersebut. Peter dan Olson (2000:110) berpendapat bahwa konsumen melakukan pembelian ulang karena adanya suatu dorongan dan perilaku membeli secara berulang yang dapat menumbuhkan suatu loyalitas terhadap apa yang dirasakan sesuai untuk dirinya.

\section{METODE PENELITIAN}

Jenis penelitian penelitian ini adalah asosiatif dengan lokasi di Lombok Epicentrum Mall Mataram, adapun alasan peneliti memilih lokasi tersebut karena Breadtalk hanya terletak di Lombok Epicentrum Mall. Populasi penelitian adalah seluruh konsumen Breadtalk Lombok Epicentrum Mall, dengan sampel sebanyak 75 responden. Teknik pengambilan sampel yang digunakan adalah purposive sampling.. 


\section{Skala Pengukuran}

Skala Likert skala yang dapat digunakan untuk mengukur sikap, pendapat, dan persepsi seseorang tentang suatu objek atau fenomena tertentu. Dengan menggunakan skala Likert, maka variabel yang akan diukur dijabarkan dari variabel menjadi dimensi, dari dimensi dijabarkan menjadi indikator, dan indikator dijabarkan menjadi subindikator yang dapat diukur. Akhirnya subindikator dapat dijadikan tolak ukur untuk membuat suatu pertanyaan atau pernyataan yang perlu dijawab oleh responden (Siregar,2013).

\section{Uji Kualitas Data}

\section{Uji Validitas}

Tabel 1. Rekapitulasi Hasil Uji Validitas

\begin{tabular}{|c|c|c|c|c|}
\hline Variabel & Item pertanyaan & $\mathbf{R}_{\text {Hitung }}$ & $\mathbf{R}_{\text {tabel }}$ & Keterangan \\
\hline \multirow{5}{*}{$\begin{array}{l}\text { Inovasi } \\
\text { Produk } \\
\text { (X1) }\end{array}$} & $\begin{array}{l}\text { Produk yang dihasilkan Breadtalk belum pernah } \\
\text { dibuat oleh produsen roti yang lainnya. }\end{array}$ & 0,763 & 0,30 & Valid \\
\hline & $\begin{array}{l}\text { Produk yang dihasilkan oleh Breadtalk memiliki } \\
\text { ciri khas yang berbeda dengan produk roti yang } \\
\text { lainnya. }\end{array}$ & 0,869 & 0,30 & Valid \\
\hline & $\begin{array}{l}\text { Produk yang dihasilkan oleh Breadtalk } \\
\text { memungkinkan dapat masuk dalam persaingan } \\
\text { penjualan roti yang telah ada. }\end{array}$ & 0,757 & 0,30 & Valid \\
\hline & $\begin{array}{l}\text { Produk yang dihasilkan oleh Breadtalk } \\
\text { melengkapi beragam produksi roti yang telah ada } \\
\text { di pasaran sehingga memunculkan banyaknya } \\
\text { pilihan. }\end{array}$ & 0,787 & 0,30 & Valid \\
\hline & $\begin{array}{l}\text { Breadtalk memberikan penawaran - penawaran } \\
\text { menarik pada saat hari - hari besar. }\end{array}$ & 0,667 & 0,30 & Valid \\
\hline \multirow{8}{*}{$\begin{array}{l}\text { Kualitas } \\
\text { Produk } \\
\text { (X2) }\end{array}$} & $\begin{array}{l}\text { Produk Breadtalk memberikan manfaat atas } \\
\text { kinerja berupa kepuasan bagi konsumen setelah } \\
\text { mengkonsumsi. }\end{array}$ & 0,780 & 0,30 & Valid \\
\hline & $\begin{array}{l}\text { Produk Breadtalk ciri khas tertentu yang dapat } \\
\text { membedakan dengan perusahaan roti lainnya. }\end{array}$ & 0,840 & 0,30 & Valid \\
\hline & $\begin{array}{l}\text { Produk Breadtalk memiliki tingkat resiko } \\
\text { kerusakan produk yang rendah. }\end{array}$ & 0,699 & 0,30 & Valid \\
\hline & $\begin{array}{l}\text { Produk Breadtalk memiliki kesesuaian } \\
\text { karakteristik dan kualitas dengan harapan } \\
\text { pelanggan. }\end{array}$ & 0,797 & 0,30 & Valid \\
\hline & $\begin{array}{l}\text { Produk Breadtalk disajikan dengan fresh, tanpa } \\
\text { bahan pengawet dan dapat bertahan cukup lama. }\end{array}$ & 0,730 & 0,30 & Valid \\
\hline & $\begin{array}{l}\text { Produk Breadtalk memiliki tampilan yang } \\
\text { manarik berupa bentuk sampai ke toping yang } \\
\text { sangat bervariasi. }\end{array}$ & 0,829 & 0,30 & Valid \\
\hline & $\begin{array}{l}\text { Produk Breadtalk memiliki kualitas atau } \\
\text { keunggulan yang berbeda dengan perusahaan roti } \\
\text { lain. }\end{array}$ & 0,800 & 0,30 & Valid \\
\hline & $\begin{array}{l}\text { Breadtalk memberikan suatu kemudahan dalam } \\
\text { memilih roti yang diinginkan dengan pelayanan } \\
\text { kasir yang baik mulai dari awal jual sampai purna } \\
\text { jual. }\end{array}$ & 0,708 & 0,30 & Valid \\
\hline
\end{tabular}

58 Pengaruh Inovasi Dan Kualitas Produk Terhadap Minat Beli Ulang ... 


\begin{tabular}{|c|c|c|c|c|}
\hline Variabel & Item pertanyaan & $\mathbf{R}$ Hitung & $\mathbf{R}_{\text {tabel }}$ & Keterangan \\
\hline \multirow{4}{*}{$\begin{array}{l}\text { Minat Beli } \\
\text { Ulang (Y) }\end{array}$} & Anda berniat membeli kembali produk Breadtalk & 0,858 & 0,30 & Valid \\
\hline & $\begin{array}{l}\text { Anda berniat untuk menyarankan produk } \\
\text { Breadtalk kepada orang lain. }\end{array}$ & 0,899 & 0,30 & Valid \\
\hline & $\begin{array}{l}\text { Anda berniat untuk mencoba produk lain yang } \\
\text { ditawarkan Breadtalk saat anda kembali. }\end{array}$ & 0,765 & 0,30 & Valid \\
\hline & $\begin{array}{l}\text { Anda tidak ragu untuk merekomendasikan } \\
\text { produk Breadtalk kepada teman dan keluarga } \\
\text { anda. }\end{array}$ & 0,839 & 0,30 & Valid \\
\hline
\end{tabular}

Sumber: Data Primer Diolah, 2019

\section{Uji Reliabilitas}

Reliabel yaitu tingkat ketetapan suatu alat test untuk mengukur sesuatu terhadap kelompok tertentu. Hal ini berarti bahwa test yang reliabel untuk satu bidang tertentu dapat digunakan kapan saja terhadap kelompok yang sama sebagaimana dimaksudkan dengan reliabilitas dari alat tes tersebut (Ali 1987:101).

Tabel 2. Rekapitulasi Hasil Uji Reliabilitas

\begin{tabular}{|l|c|c|}
\hline \multicolumn{1}{|c|}{ Variabel } & Alpha Cronbach & Keterangan \\
\hline Inovasi Produk & 0,796 & Reliabel \\
\hline Kualitas Produk & 0,784 & Reliabel \\
\hline Minat Beli Ulang & 0,784 & Reliabel \\
\hline
\end{tabular}

Sumber: Data Primer Diolah, 2019

\section{Analisis Regresi Berganda}

Analisis yang digunakan untuk mengetahui seberapa besar pengaruh lebih dari satu variabel bebas terhadap satu variabel terikat (Ghozali, 2005:105). Metode ini menghubungkan satu variabel dependen dengan banyak variabel independen. Dalam penelitian ini yang menjadi variabel terikat adalah minat beli ulang, sedangkan yang menjadi variabel bebas adalah inovasi dan kualitas produk. Model hubungan loyalitas pelanggan dengan variabel-variabel bebasnya tersebut disusun dalam fungsi atau persamaan sebagai berikut:

Rumus $=\mathrm{Y}=\mathrm{a}+\mathrm{b}_{1} \mathrm{X}_{1}+\mathrm{b}_{2} \mathrm{X}_{2}+e$

Keterangan:

$\mathrm{Y}=$ Minat Beli Ulang

$\mathrm{a}=$ Konstanta

$\mathrm{X}_{1}=$ Inovasi Produk

$\mathrm{X}_{2}=$ Kualitas Produk

$e=$ Standard error

\section{Uji Hipotesa}

\section{Uji signifikansi Parameter Individual (Uji t)}

Uji statistik t pada dasarnya menunjukkan seberapa jauh pengaruh satu variabel penjelas atau independen secara individual dalam menerangkan variasi variabel dependen Ghozali (2005:58). Pengujian ini bertujuan untuk menguji pengaruh variabel bebas (inovasi produk dan kualitas produk) terhadap variabel 
terikat (minat beli ulang) secara terpisah ataupun bersama-sama. Untuk menguji variabel yang berpengaruh antara $\mathrm{X} 1, \mathrm{X} 2$ terhadap $\mathrm{Y}$ secara terpisah maupun bersama-sama, maka digunakan uji t. Adapun kriteria pengujian uji t adalah sebagai berikut:

$>$ Jika signifikansi $<0,05$ maka $\mathrm{H} 1$ diterima berarti ada pengaruh signifikan variabel independen secara individual terhadap variabel dependen.

2. Jika signifikansi $>0,05$ maka $\mathrm{H} 1$ ditolak berarti tidak ada pengaruh signifikan variabel independen secara individual terhadap variabel dependen.

\section{Uji f (Goodness Of Fit)}

Menurut Ferdinand (2014), uji F atau uji kelayakan model dilakukan untuk melihat apakah model yang dianalisi memiliki tingkat kelayakan model yang tinggi yaitu variabel-variabel yang digunakan mampu untuk menjelaskan fenomena yang dianalisis. Uji keterandalan model atau uji kelayakan model atau yang lebih populer disebut sebagai uji F merupakan tahapan awal mengidentifikasi model regresi yang diestimasi layak atau tidak. Layak (andal) disini maksudnya adalah model yang diestimasi layak digunakan untuk menjelaskan pengaruh variabel-variabel bebas terhadap variabel terikat. Nama uji ini disebut sebagai uji F, karena mengikuti distribusi F yang kriteria pengujiannya seperti One Way Anova.

Apabila nilai prob. F hitung (ouput SPSS ditunjukkan pada kolom sig.) lebih kecil dari tingkat kesalahan/error (alpha) 0,05 (yang telah ditentukan) maka dapat dikatakan bahwa model regresi yang diestimasi layak, sedangkan apabila nilai prob. $\mathrm{F}$ hitung lebih besar dari tingkat kesalahan 0,05 maka dapat dikatakan bahwa model regresi yang diestimasi tidak layak.

\section{Koefisien Determinasi (R2)}

Untuk mengukur seberapa besar kontribusi variabel independen terhadap variabel dependen secara parsial digunakan koefisien determinasi. Nilai koefisien determinasi adalah antara nol dan satu. Nilai R2 yang kecil berarti kemampuan variabel-variabel independen dalam menjelaskan variasi variabel dependen sangat terbatas. Nilai yang mendekati satu berarti variabel-variabel independen memberikan hampir semua informasi yang dibutuhkan untuk memprediksi variasi variabel dependen (Ghozali, 2013: 46).

\section{HASIL DAN PEMBAHASAN}

\section{Analisis Data}

\section{Uji Normalitas Data}

Berikut hasil perhitungan dari uji normalitas dengan pendekatan Kolmogorov Smirnov:

Tabel 3. Hasil Uji Normalitas Data

\begin{tabular}{|l|l|r|}
\hline \multicolumn{2}{|l|}{} & $\begin{array}{c}\text { Unstandardized } \\
\text { Residual }\end{array}$ \\
\cline { 3 - 3 } $\mathrm{N}$ & Mean & 75 \\
\cline { 3 - 3 } Normal Parameters & Std. Deviation &, 0000000 \\
\hline
\end{tabular}




\begin{tabular}{|l|l|r|}
\hline Most Extreme Differences & Absolute &, 094 \\
\cline { 2 - 3 } & Positive &, 094 \\
\cline { 2 - 3 } & Negative &,- 049 \\
\hline \multicolumn{2}{|l|}{} &, 094 \\
\hline Test Statistic &, $098^{\mathrm{c}}$ \\
\hline
\end{tabular}

Sumber: Data Primer Diolah, 2019

Berdasarkan hasil pengujian dengan pendekatan Kolmogorov Smirnov, diperoleh angka probabilitas atau Asym. Sig. (2-tailed) yaitu 0,098. Dapat diketahui bahwa nilai signifikansi lebih besar dari $\alpha=0.05$, maka dapat disimpulkan bahwa data berdistribusi normal, sehingga model layak sebagai alat analisa data.

\section{Uji Multikolineritas}

Tabel 4. Hasil Uji Multikolinieritas

\begin{tabular}{|c|c|c|c|}
\hline Variabel & Tolerance & VIF & Keterangan \\
\hline Inovasi Produk & 0,367 & 2,726 & $\begin{array}{c}\text { Model Bebas } \\
\text { Multikolinieritas }\end{array}$ \\
\hline Kualitas Produk & 0,367 & 2,726 & \\
\hline
\end{tabular}

Sumber: Data Primer Diolah, 2019

Berdasarkan Tabel di atas maka dapat diketahui bahwa tidak ada variabel bebas yang memiliki nilai tolerance kurang dari 0.1 yang berarti bahwa tidak ada korelasi antar variabel bebas. Hasil nilai VIF juga menunjukkan hasil serupa, bahwa tidak ada variabel bebas yang memiliki nilai VIF lebih dari 10. Dapat disimpulkan bahwa tidak ada masalah multikolinieritas antar variabel bebas yaitu antara variabel inovasi dan kualitas produk dalam model regresi.

\section{Uji Heterokedastisitas}

Tabel 5. Rekapitulasi Hasil Uji Heterokedastisitas

\begin{tabular}{|l|c|}
\hline \multicolumn{1}{|c|}{ Variabel } & Sig. (2-tailed) \\
\hline Inovasi Produk (X1) & 0,542 \\
\hline Kualitas Produk(X2) & 0,962 \\
\hline
\end{tabular}

Sumber: Data Primer Diolah, 2019

Tabel menunjukkan bahwa seluruh nilai signifikan lebih besar dari 0,05. Dengan demikian dapat disimpulkan bahwa tidak terjadi heterokedastisitas antara variabel-variabel yang digunakan dalam penelitian ini.

\section{Analisis Regresi Berganda}

Teknik analisis regresi linier berganda bertujuan untuk mengukur seberapa besar pengaruh inovasi produk (X1) dan kualitas produk (X2) terhadap minat beli ulang (Y). Hasil analisis diperoleh sebagai berikut: 
Tabel 6. Ringkasan Hasil Regresi Linier Berganda

\begin{tabular}{|c|c|c|c|c|c|c|}
\hline \multirow{2}{*}{ Model } & \multicolumn{2}{|c|}{ Unstandardized Coefficients } & $\begin{array}{c}\text { Standardized } \\
\text { Coefficients }\end{array}$ & \multirow{2}{*}{ t } & \multirow{2}{*}{ Sig. } \\
\cline { 3 - 5 } \multicolumn{2}{|c|}{} & B & Std. Error & Beta & & \\
\hline \multirow{2}{*}{1} & (Constant) & 1,143 &, 365 & & 3,129 &, 003 \\
\cline { 2 - 7 } & X1 &, 270 &, 128 &, 282 & 2,108 &, 038 \\
\cline { 2 - 7 } & X2 &, 518 &, 144 &, 482 & 3,608 &, 001 \\
\hline
\end{tabular}

Sumber: Data Primer Diolah, 2019

Berdasarkan Tabel diperoleh persamaan regresi linier berganda sebagai berikut:

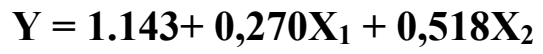

Dari hasil analisis linier berganda dapat dianalisis beberapa hal, antara lain:

a. Nilai konstanta sebesar 1.143 menunjukkan bahwa variabel inovasi dan kualitas produk jika nilainya 0 maka minat beli ulang secara matematis nilainya diukur secara numerik sebesar 1.143. Dapat dilihat bahwa variabel minat beli ulang sebelum dipengaruhi oleh variabel inovasi dan kualitas produk nilainya sebesar 1.143 lebih besar daripada nilai koefisien regresi variabel inovasi dan kualitas produk, maka dapat diketahui bahwa ada faktor yang lebih besar mempengaruhi minat beli ulang selain inovasi dan kualitas produk. Faktor lainnya seperti, harga, lokasi outlet dan program promosi yang biasanya menjadi faktor dominan dalam minat beli ulang tidak termasuk dalam variabel yang diteliti.

b. Koefisien regresi untuk variabel inovasi produk (X1) sebesar 0,270 dengan nilai positif, artinya bahwa jika terjadi peningkatan pada variabel inovasi produk sebesar $100 \%$ maka akan terjadi peningkatan juga pada variabel minat beli ulang sebesar 0,270 dengan asumsi variabel yang lain konstan atau tidak mengalami perubahan.

c. Koefisien regresi untuk variabel kualitas produk (X2) sebesar 0,518 dengan nilai positif artinya bahwa jika terjadi peningkatan pada variabel kualitas produk sebesar 100\% maka akan terjadi peningkatan juga pada variabel minat beli ulang sebesar 0,518 dengan asumsi variabel yang lain konstan atau tidak mengalami perubahan.

\section{Uji T}

Uji statistik t pada dasarnya menunjukkan seberapa jauh pengaruh satu variabel penjelas atau independen secara individual dalam menerangkan variasi variabel dependen. Dalam penelitian ini menggunakan tingkat kepercayaan 95\% dengan $\alpha=5 \%(0.05)$ maka $\mathrm{t}$ tabel $=(\alpha / 2 ; \mathrm{n}-\mathrm{k}-1)=\mathrm{t}(0.025 ; 72)=1.994$. Hasil pengujian dapat dilihat pada Tabel berikut:

Tabel 7. Hasil Uji t

\begin{tabular}{|c|c|c|c|c|c|c|}
\hline & \multirow[t]{2}{*}{ Model } & \multicolumn{2}{|c|}{$\begin{array}{l}\text { Unstandardized } \\
\text { Coefficients }\end{array}$} & \multirow{2}{*}{$\begin{array}{c}\begin{array}{c}\text { Standardized } \\
\text { Coefficients }\end{array} \\
\text { Beta } \\
\end{array}$} & \multirow[t]{2}{*}{$\mathbf{t}$} & \multirow[t]{2}{*}{ Sig. } \\
\hline & & B & Std. Error & & & \\
\hline \multirow[t]{3}{*}{1} & (Constant) & 1,143 & ,365 & & 3,129 & ,003 \\
\hline & $\mathrm{X} 1$ & 270 &, 128 & ,282 & 2,108 &, 038 \\
\hline & $\mathrm{X} 2$ & ,518 & , 144 & ,482 & 3,608 &, 001 \\
\hline
\end{tabular}

Sumber: Data Primer Diolah, 2019 
Berdasarkan Tabel di atas, dapat dilihat bahwa:

a. Pengujian Hipotesis : Inovasi Produk Terhadap Minat Beli Ulang

Berdasarkan hasil uji statistik diperoleh nilai $\mathrm{T}_{\text {hitung }}$ 2,108 lebih besar dari $\mathrm{T}_{\text {tabel }}$ 1,994. Dari level signifikansi yaitu 0,038 dimana nilai signifikansi di bawah 0,05. Hal ini menunjukkan bahwa variabel inovasi produk berpengaruh positif dan signifkan terhadap minat beli ulang konsumen Breadtalk.

b. Pengujian Hipotesis : Pengaruh Kualitas Produk Terhadap Minat Beli Ulang

Berdasarkan hasil uji statistik diperoleh nilai Thitung 3,608 lebih besar dari $\mathrm{T}_{\text {tabel }}$ 1.994. Dari level signifikansi yaitu 0,01 dimana nilai signifikansi di bawah 0.05. Hal ini menunjukkan bahwa variabel kualitas produk berpengaruh positif dan signifkan terhadap minat beli ulang konsumen Breadtalk.

\section{Uji f (Goodness Of Fit)}

Uji kelayakan model atau goodness of fit dilakukan untuk menguji apakah variabel-variabel yang diteliti dalam penelitian ini menggunakan model yang layak dan memiliki tingkat kelayakan yang tinggi untuk dapat menjelaskan fenomena yang dianalisis. Untuk menguji kelayakan model dilakukan dengan menggunakan uji $\mathrm{f}$. Hasil uji f dapat dilihat pada Tabel 4.9 berikut :

Tabel 8. Hasil Uji F (Goodness Of Fit)

\begin{tabular}{|l|l|r|r|r|r|r|}
\hline \multicolumn{2}{|c|}{ Model } & $\begin{array}{c}\text { Sum of } \\
\text { Squares }\end{array}$ & \multicolumn{1}{c|}{ df } & Mean Square & F & Sig. \\
\hline \multirow{3}{*}{1} & Regression & 16,530 & 2 & 8,265 & 40,304 &, $000^{\mathrm{b}}$ \\
\cline { 2 - 7 } & Residual & 14,765 & 72 &, 205 & & \\
\cline { 2 - 7 } & Total & 31,295 & 74 & & & \\
\hline \multicolumn{2}{|l|}{ Sumber: Data Primer Diolah, 2019 } \\
\hline
\end{tabular}

Berdasarkan Tabel 4.9 di atas, diperoleh nilai Fhitung sebesar 40,304 dengan menggunakan tingkat kepercayaan $95 \%$ atau $\alpha=5 \%(0,05)$ dan $\mathrm{F}_{\text {tabel }}=\mathrm{F}(\mathrm{k} ; \mathrm{n}-\mathrm{k}-1)=$ $\mathrm{F}(2 ; 72)=3,12$. Hasil yang diperoleh yaitu $F_{\text {hitung }}>F_{\text {tabel }}(40,304>3,12)$ dan tingkat probabilitas sebesar $0,000<0.05$ maka dapat disimpulkan bahwa variabel bebas yang digunakan yaitu inovasi dan kualitas produk merupakan variabel yang tepat/layak untuk menjelaskan terjadinya variasi dalam variabel minat beli ulang.

\section{Koefisien Determinasi $\left(\mathbf{R}^{2}\right)$}

Koefisien determinasi $\left(\mathrm{R}^{2}\right)$ digunakan untuk mengukur kontribusi variabel bebas (X1 dan X2) terhadap variabel terikat (Y). Koefisien ini menunjukkan seberapa besar persentase variasi variabel independen yang digunakan dalam model mampu menerangkan variasi variabel dependen.

Hasil uji koefisien determinasi $\left(\mathrm{R}^{2}\right)$ sebagai berikut:

Tabel 9. Hasil Uji Koefisien Determinasi (R2)

\begin{tabular}{|l|r|r|r|r|}
\hline Model & \multicolumn{1}{|c|}{ R } & R Square & Adjusted R Square & Std. Error of the Estimate \\
\hline 1 &, $727^{\mathrm{a}}$ &, 528 &, 515 &, 45285 \\
\hline
\end{tabular}

Sumber: Data Primer Diolah, 2018

Berdasarkan Tabel 4.10 di atas maka diperoleh nilai Adjust R Square sebesar 0,515 atau $51,5 \%$. Dimana hal ini menunjukkan bahwa sumbangan atau kontribusi 
variabel bebas (inovasi dan kualitas produk) terhadap variabel terikat yaitu minat beli ulang konsumen Breadtalk adalah sebesar 51,5\% dan sisanya sebesar 48,5\% dipengaruhi oleh variabel atau faktor lain di luar model penelitian ini.

\section{Pembahasan}

Dalam penelitian ini, peneliti ingin mengetahui pengaruh dari inovasi dan kualitas produk terhadap minat beli ulang konsumen Breadtalk di Lombok Epicentrum Mall. Dari hasil analisis data yang telah dipaparkan di atas, selanjutnya dapat diinterpretasikan hasil penelitian sebagai berikut:

a. Berdasarkan pada hasil pengujian menunjukkan bahwa hipotesis pertama (H1) yang menduga bahwa inovasi produk berpengaruh signifikan terhadap Minat beli ulang konsumen Breadtalk di Lombok Epicentrum Mall dapat diterima.

Secara perhitungan statistik, variabel inovasi produk mempunyai pengaruh yang signifikan dengan nilai thitung sebesar 2,108 lebih besar dari tabel 1,994 dengan signifikansi yaitu 0,038 yang berarti inovasi produk berpengaruh signifikan terhadap minat beli ulang. Hasil ini didukung oleh penelitian Andrawan Diponugroho (2015) Tika Septiani (2013) yang hasil penelitiannya menunjukan bahwa inovasi produk berpengaruh signifikan terhadap minat beli ulang konsumen.

Hasil penelitian pada variabel Inovasi produk memiliki tanggapan positif. Dimana indikator produk baru bagi dunia, lini produk baru, dan lini produk yang telah ada rata - rata memiliki kategori yang tinggi. Hasil ini menunjukkan bahwa rata-rata Inovasi produk Breadtalk sudah memenuhi kepuasan konsumen, kemudian akan mampu untuk bersaing dengan produsen roti lainnya dan dapat menimbulkan minat beli ulang konsumen. Sesuai dengan pendapat Cooper (2000: 38), bahwa keunggulan produk baru sangat penting dalam lingkungan pasar global yang sangat kompetitif. Keunggulan tersebut tidak lepas dari pengembangan produk inovasi yang dihasilkan sehingga akan mempunyai keunggulan di pasar yang selanjutnya akan menang dalam persaingan.

b. Berdasarkan pada hasil pengujian menunjukkan bahwa hipotesis kedua (H2) yang menduga bahwa kualitas produk berpengaruh signifikan terhadap Minat beli ulang konsumen Breadtalk Lombok Epicentrum Mall dapat diterima.

Secara perhitungan statistik seperti diatas, variabel Kualitas produk mempunyai pengaruh yang signifikan dengan nilai thitung sebesar 3,608 lebi besar dari tabel yaitu 1,994 dan tingkat signifikansi sebesar 0,001. Kdapat diartikan bahwa Kualitas Produk berpengaruh signifikan terhadap minat beli ulang. Hasil ini didukung oleh penelitian Andrawan Diponugroho (2015), dan Lurensia Vinda W. (2015) yang hasil penelitiannya menunjukkan bahwa Kualitas Produk berpengaruh signifikan terhadap minat beli ulang.

Hasil penelitian pada variabel Kualitas produk memiliki tanggapan positif. Dimana indikator kualitas produk yang digunakan dalam penelitian ini adalah Kinerja (Performance), Fitur (Features), Keandalan (Reliability), Kesesuaian dengan spesifikasi (Conformance to specification), Daya tahan (Durability), Estetika (Asthetics), Kualitas yang dipersepsikan (Perceived quality), Kemudahan perbaikan (Serviceability). Hasil ini menunjukkan produk yang berkualitas dan terjamin akan membuat konsumen yakin dengan produk yang akan dikonsumsinya tersebut. Begitu 
pula dalam penelitian yang dilakukan oleh Prabowo 2002 dalam Ferdinand (2006: 129) menyatakan bahwa jika kualitas produk yang dihasilkan oleh perusahaan dapat memenuhi selera pelanggan, maka produk- produk akan selalu diminati dan dicari oleh pelanggan. Tampilan produk yang beragam jenis serta kesesuaian dengan harapan pelanggan terhadap produk tersebut juga akan memberi kepuasan tersendiri sehingga membuat konsumen berniat untuk melakukan pembelian kembali.

c. Berdasarkan pada hasil pengujian menunjukkan bahwa hipotesis ketiga (H2) yang menduga bahwa terdapat variabel yang dominan mempenagruhi Minat beli ulang konsumen Breadtalk Lombok Epicentrum Mall dapat diterima.

Besaran pengaruh variabel independen terhadap variabel dependen dilambangkan dengan Beta ( $\beta$ ). $\beta$ dapat bernilai negatif maupun positif. Nilai $\beta$ inilah yang menunjukkan variabel mana yang paling dominan. Selain itu, signifikan atau tidak signifikan juga mempengaruhi pemilihan variabel mana yang paling dominan.

Secara perhitungan statistik uji t seperti diatas, telah diketahui nilai $\beta$ pada Standardized Coefficients untuk variabel inovasi produk sebesar 0,282 dengan signifikasi $0,038<0,05$ dengan nilai positif, sedangkan untuk nilai $\beta$ pada variabel kualitas produk sebesar 0,482 dengan signifikasi 0,001<0,05. Dengan demikian, memilih variabel kualitas produk sebagai variabel paling dominan mempengaruhi merupakan pilihan yang tepat, karena memiliki nilai $\beta$ lebih besar dibandingkan dengan variabel inovasi produk.

\section{KESIMPULAN DAN SARAN}

\section{Kesimpulan}

Berdasarkan hasil analisis dan pembahasan, maka dapat diperoleh kesimpulan bahwa : variabel inovasi produk memiliki pengaruh signifikan terhadap minat beli ulang produk Breadtalk. Demikian juga halnya dengan variabel kualitas produk memiliki pengaruh yang signifikan terhadap minat beli ulang produk Breadtalk, akan tetapi diantara kedua variabel tersebut ternyata variabel kualitas produk memliki pengaruh lebih besar dibandingkan variabel inovasi produk.

\section{Saran}

Saran yang dapat diberikan sesuai dengan hasil penelitian ini adalah karena inovasi produk belum memberikan pengaruh yang besar terhadap minat beli ulang, maka sebaiknya perusahaan melakukan inovasi secara berkesinambungan seperti menciptakan produk yang lebih beragam dan bervariasi, mengunah bentuk dan topingnya agar lebih unk sehingga bisa menjadi trendsetter bagi produsen roti di Indonesia. Selain itu perlu digencarkan komunikasi pemasaran yang menginformasikan adanya inovasi-inovasi produk baru. 


\section{DAFTAR PUSTAKA}

Anoraga, Pandji (2005), Manajemen Bisnis, Jakarta, Rhineka Cipta.

Assauri, Sofjan.2014. Manajemen Pemasaran, Jakarta, Raja Grafindo Persada, Buchari, Alma. (2007). Manajemen Pemasaran \& Manajemen Jasa. Bandung. Alfabeta.

Cooper, D R. And Emory, C W., 2000, Business Research Methods, 5thedition, Richard D. Irwin Inc.

Djarwanto, PS. danSubagyo, Pangestu. 1998. StatistikInduktif. Jakarta: BPFE.

Ferdinand, 2002. Metode Penelitian Manajemen : Pedoman penelitian untuk Skripsi, Tesis, dan Desertasi Ilmu Manajemen, Semarang : Badan Penerbit Universitas Diponegoro.

Ferdinand, Augusty. 2006. Metode Penelitian Manajemen : Pedoman Penelitian Untuk Penulisan Skripsi, Tesis, dan Disertasi Ilmu Manajemen. Semarang: Badan Penerbit Universitas Diponegoro.

Ferdinand, Augusty.2014. Metode Penelitian Manajemen.Semarang : Badan Penerbit Univ. Diponogoro.

Garvin, D.A. 1988. Managing Quality.New York: The Free Press.

Ghozali, Imam. 2013. Aplikasi Analisis Multivariate dengan program SPSS edisi ketujuh. Semarang: Badan Penerbit UNDIP.

Hill, Liz dan Terry O’Sulivan (2004): Foundation Marketing 3rd Edition, Harlow, Pearson Education Ltd.

Kotler, Philip. 2005. Dasar-Dasar Pemasaran 1. Edisi Bahasa Indonesia.Jakarta: Perhalindo.

Kotler, Philip. 2005. Manajemen Pemasaran. Alih Bahasa Benyamin Molan. Jakarta: Indeks.

Kotler, Philip. 2008. Manajemen Pemasaran Edisi 12 Jilid 2. Jakarta: Indeks.

Kotler, Philip dan Armstrong. 2007. Dasar - dasar pemasaran. Edisi kesembilan. Cetakan kedua. Pt. Indeks: Jakarta.

Kotler, Philip dan Keller K Lane,2007. Manajemen Pemasaran, edisi 12 jilid 1. Jeresey: Prentice Hall.

Kotler, Philip dan Keller K Lane. 2009. Manajemen Pemasaran jilid 1 edisi 13. Jakarta: PT Indeks.

Kotler, Philip and Amstrong, Gary. 2012. Priciples of Marketing Global 14thedition. New Jersey: Prentice. 
Kotler, Philip and Keller, Kevin Lane. 2012. Marketing Management. 14th edition. New Jersey: Prentice.

McCharty, Jerome, E,; Perreault, William D, 2003, Dasar-dasar Pemasaran, Edisi kelima, alih Bahasa: Agus Darma, Jakarta : Erlangga.

Mulyono, Bayu Hadyanto, Yoestini, Rini Nugraheni, Mustofa Kamal. 2007. Analisis Pengaruh Kualitas Produk Dan Kualitas Layanan Terhadap Kepuasan Konsumen (Studi Kasus Pada Perumahan Puri Mediterania Semarang). JURNAL STUDI MANAJEMEN \& ORGANISASI Volume 4, Nomor 2, Juli, Tahun 2007, Halaman 91.

Nazir, Moh. 2005. Metode Penelitian. Jakarta: Ghalia Indonesia.

Peter, J. Paul dan Jerry C Olson. 2002. Perilaku Konsumen dan Strategi Pemasaran. Terjemahan. Jakarta: Erlangga.

Peter dan irawan. 2008. Pengaruh Inovasi Produk dan Kelompok Referensi Terhadap Minat Beli hp high end di Surabaya. Surabaya:petra Christianuniversity library.

Peter, JP dan Olson, JC (2000), Perilaku Konsumen dan Strategi pemasaran, Jakarta, Erlangga

Peter dan Olson (2010).Consumer Behavior.Edisi 4, Jilid 2:Erlangga, Jakarta.

Rogers, E. M. (1995). Diffusion of Innovations. New York: The Free Press.

Sekaran, uma dan Roger Bougie. (2010). Edisi 5, Research Method For Business: A Skill Building Approach. John Wiley@ Sons, New York (E-Books).

Siregar, Syofian. 2013. Metode Penelitian Kuantitatif. Jakarta:PT Fajar Interpratama Mandiri.

Solomon, MR,Stuart WE (1997),Marketing:Real People,Real Choices International Edition,New Jersey:Prentice Hall.

Suliyanto. 2006. MetodeRisetBisnis. Yogyakarta: Andi.

Sutrisno, Hadi. 2002. Metodologi Riset. Yogyakarta: Andi Ofset.

Susanto, Agus. 2013. Pengaruh promosi, harga dan inovasi produk terhadap keputusan pembelian pada batik tulis karang melati demak. Semarang: Universitas Negeri Semarang.

Sutoyo, Anwar. 2009. Pemahaman Individu, Observasi, Checklist, Interviu, Kuesioner dan Sosiometri. Yogyakarta: Pustaka Pelajar.

Swastha, Basu (2005). Manajemen Pemasaran Modern Yogyakarta: Liberty.

Tjiptono, Fandy. 2001. Strategi Pemasaran. Yogyakarta: Andi Offset.

Tjiptono, Fandy. 1997. Strategi Pemasaran (Edisi Kedua). Yogyakarta: Andi Offset. 
Tjiptono, Fandy. 2008. Strategi Pemasaran Edisi III. Yogyakarta.

Walker, Orville C, Boyd Harper W dan Jane Claude Larrache (2005) : Manajemen Pemasaran, Suatu pendekatan Strategis Dengan Orientasi Global, Jakarta, Erlangga

http://www.Breadtalk .co.id (Kamis, 01-11-2018).

http://dianfajarsarwiasti.blogspot.com/2013/11/Breadtalk-vs-breadlife-Breadtalk.html (Sabtu,1-12-2018). 